Tropical Journal of Pharmaceutical Research October 2017; 16 (10): 2395-2401

ISSN: $1596-5996$ (print); 1596-9827 (electronic)

(C) Pharmacotherapy Group, Faculty of Pharmacy, University of Benin, Benin City, 300001 Nigeria.

All rights reserved.

Available online at http://www.tjpr.org

Original Research Article

http://dx.doi.org/10.4314/tjpr.v16i10.12

\title{
Effects of flavonoids extracted from the whole plant of Patrinia Villosa (Thunb) Juss in a rat model of chronic pelvic inflammation
}

\author{
Xiao-xiao $\mathrm{Li}^{1,2}$, Cui-fang Hao ${ }^{2 \star}$, Yuan-qi He${ }^{3}$, Hai-ning Liu ${ }^{3}$ and Xiao-na $\mathrm{Li}^{4}$ \\ ${ }^{1}$ Shandong University, Jinan 250100, ${ }^{2}$ Reproductive Medicine Centre, Yuhuangding Hospital of Yantai, Affiliated Hospital of \\ Qingdao University, Yantai 264000, ${ }^{3}$ Department of Obstetrics and Gynecology, ${ }^{4}$ Department of Neurosurgery, Weihai \\ Municipal Hospital, Weihai 264200, PR China
}

*For correspondence: Email: rmchao@yeah.net; Tel/Fax: +86-535-6691999

Revised accepted: 11 September 2017

\begin{abstract}
Purpose: To investigate the effects of total flavonoids (PLV) extracted from the whole plant of Patrinia Villosa (Thunb.) Juss (PTJ) in a rat model of chronic pelvic inflammation.

Methods: An orthogonal test design was employed to optimize the extraction conditions of PLV via reflux extraction by ethanol. Rats were randomly divided into control group, model group and PLV groups. An absorbable gelatin sponge with pathogens was inserted into the cervix of the rat to establish a pelvic inflammatory model. The PLV groups were orally administered PLV at doses of 25, 50 and 100 $\mathrm{mg} / \mathrm{kg}$ for eight days. Enzyme-linked immunosorbent assay (ELISA) was used for the determination of inflammatory cytokines in rat serum and the culture supernatant of RAW264.7 cells. Real-time reverse transcription polymerase chain reaction (real-time PCR) was employed to determine IRNA levels.

Results: The optimum extraction conditions for PLV by orthogonal test were obtained: extraction time $(120 \mathrm{~min})$, ratio of liquid to raw material $(20 \mathrm{~mL} / \mathrm{g})$ and ethanol concentration $(50 \%)$. By treating with $P L V$, the levels of TNF- $\alpha, I L-6$ and IL-1 $\beta$ significantly decreased $(p<0.01)$, while IL-10 level significantly increased $(p<0.01)$ in the serum of chronic pelvic inflammatory rats and LPS-stimulated macrophages. In addition, a similar trend was observed in the MRNA levels of LPS-stimulated macrophages treated with PLV.
\end{abstract}

Conclusion: PLV showes significant anti-inflammatory effects on chronic pelvic inflammation. The potential mechanism is related to regulating the expression of inflammatory factors

Keywords: Patrinia Villosa (Thunb.) Juss, Total flavonoids, Chronic pelvic inflammation, Inflammatory cytokines

Tropical Journal of Pharmaceutical Research is indexed by Science Citation Index (SciSearch), Scopus, International Pharmaceutical Abstract, Chemical Abstracts, Embase, Index Copernicus, EBSCO, African Index Medicus, JournalSeek, Journal Citation Reports/Science Edition, Directory of Open Access Journals (DOAJ), African Journal Online, Bioline International, Open-J-Gate and Pharmacy Abstracts

\section{INTRODUCTION}

Pelvic inflammatory disease (PID) is a common gynecological disease which seriously affects the life quality of woman, and it usually causes chronic pelvic pain, tubal factor infertility, and ectopic pregnancy. The etiopathogenisis of PID is the infection of pathogenic microorganisms in upper genital tract which causes endometritis, salpingitis, and peritonitis, etc. $[1,2]$. Chlamydia trachomatis and Neisseria gonorrhoeae were proved to be the most common pathogen causes of PID [3]. Antibiotics are usually used for the treatment of PID to reduce short-term morbidity. However, they have no effects on long term complications induced by PID [4]. In addition, bacterial drug resistance and drug side effects limit the clinical use of antibiotics [5]. Therefore, 
new drugs are needed for inhibiting the progression and alleviating the long-term sequelae of PID.

Patrinia villosa (Thunb.) Juss. (PTJ), called Baijiangcao in Chinese, is an important herbal medicine which has been used in China for more than 2000 years. It belongs to the family of Valerianaceae, and has been used in Traditional Chinese Medicine (TCM) for treating inflammation, wound and abdominal pain [6]. Previous reports have revealed that triterpenoid saponins, iridoids, flavonoids, flavonones, and polysaccharides are the major bioactive constituents in PTJ, which displayed anti-tumor and anti-inflammatory activities [7]. However, to the best of our knowledge, there is no report regarding the effects of flavonoids from $\mathrm{PTJ}$ on chronic pelvic inflammatory disease. In the present study, orthogonal design was used to optimize the extraction conditions of flavonoids from PTJ, and their effects on chronic pelvic inflammation were studied in vivo and in vitro.

\section{EXPERIMENTAL}

\section{Chemicals and reagents}

Rutin standard was obtained from National Institute for Food and Drug Control (Beijing, China). ELISA kits for interleukin (IL)-1及, tumor necrosis factor (TNF)- $\alpha$, IL- 6 and IL-10 were obtained from R\&D Systems (Minneapolis, MN, USA). Cell Counting Kit-8 (CCK-8) was obtained from Dojindo (Kumamoto, Japan). Absorbable gelatin sponge was purchased from Jinling Pharmaceutical Co. (Nanjing, China). The herbs of PTJ was purchased from an herbal medicine market (Ji'nan, China), and authenticated by a taxonomist in the Department of Traditional Chinese Medicine in Yuhuangding Hospital of Yantai (Yantai, China). A voucher specimen (no. CYC-20160803) was deposited in the herbarium of Yuhuangding Hospital of Yantai (Yantai, China).

\section{Extraction of flavonoids (FLV) from PTJ}

PTJ was dried in a drying oven at $50{ }^{\circ} \mathrm{C}$ and $10 \mathrm{~g}$ powder was extracted by reflux with designed extraction conditions (extraction time, ratio of liquid to raw material and ethanol concentration) (Table 1). The solutions were collected and cooled to room temperature. After centrifuging at $3000 \mathrm{rpm}$ for $10 \mathrm{mins}$, the supernatants were collected and filtered through a nylon filter $(0.22$ $\mu \mathrm{m})$. The determination of flavonoids was performed by using the aluminum nitrate colorimetric method at $500 \mathrm{~nm}$ [8]. Rutin was used as the standard to calculate the total flavonoid content.

Table 1: Factors and their levels used in the orthogonal design

\begin{tabular}{lccc}
\hline \multirow{2}{*}{ Factor } & \multicolumn{3}{c}{ Level } \\
\cline { 2 - 4 } & $\mathbf{1}$ & $\mathbf{2}$ & $\mathbf{3}$ \\
\hline $\begin{array}{l}\text { A: Extraction time (min) } \\
\text { B: Ratio of liquid to raw } \\
\text { material }(\mathrm{mL} / \mathrm{g})\end{array}$ & 60 & 120 & 180 \\
$\begin{array}{l}\text { C: Ethanol } \\
\text { concentration (\%) }\end{array}$ & 10 & 20 & 30 \\
\hline
\end{tabular}

\section{Optimization of flavonoid extraction}

In the present study, an orthogonal test $\left(\mathrm{L}_{9}\left(3^{4}\right)\right)$ was used to investigate the effects of extraction time (min), ratio of liquid to raw material $(\mathrm{mL} / \mathrm{g})$, and ethanol concentration (\%) on the extraction yield of PLV. The factors and experimental data are shown in Table 1 and Table 2.

\section{Animals}

Female Sprague-Dawley (SD) rats (aged 12 weeks, $190 \pm 10 \mathrm{~g})$ were obtained from Laboratory Animal Center of Shandong University (Jinan, China). All rats were housed in an controlled environment $\left(21 \pm 2{ }^{\circ} \mathrm{C}, 55 \pm 5 \%\right.$ humidity) with a $12 \mathrm{~h}$ light/12 h dark cycle. All procedures of animal experiments in the present study were approved by Institutional Animal Care and Use Committee at Yuhuangding Hospital of Yantai (approval no. 201609-1L) and in accordance with "Principles of Laboratory Animal Care" (NIH publication no. 85-23, revised 1985) [9].

\section{Cell culture}

Murine macrophage RAW 264.7 cells was obtained from the American Type Culture Collection (ATCC, USA). Cells were maintained in Dulbecco's modified Eagle's medium (DMEM) with $10 \%$ fetal bovine serum (FBS) and antibiotics $(100 \mathrm{mg} / \mathrm{mL}$ streptomycin and 100 $\mathrm{U} / \mathrm{mL}$ penicillin), and cultured in $5 \% \mathrm{CO}_{2} / 95 \%$ air at $37^{\circ} \mathrm{C}$.

\section{Determination of anti-inflammatory effect of PLV}

After acclimation for 7 days, the rats were injected progesterone (10 mg) subcutaneously. The PID model was constructed using the previous method with some modifications [10]. An absorbable gelatin sponge $\left(0.125 \mathrm{~mm}^{3}\right)$ was immersed in the mixed pathogen solution $(1 \times$ $10^{8} \mathrm{ccu} / \mathrm{mL} U$. urealyticum ( $t$-strain mycoplasma) and $1 \times 10^{8} \mathrm{cfu} / \mathrm{mL}$ pathogenic $E$. coli). Then the 
gelatin sponge was inserted into the cervix of each rat and the rat was forced upside down for 5 min. A gelatin sponge without microbe was inserted into the cervix of each rat in control group. Infections were performed for four times with a 2-day interval. PLV were orally administrated at the doses of 25,50 and 100 $\mathrm{mg} / \mathrm{kg}$ for eight days. Thereafter, the rats were anaesthetized by injecting pentobarbital (30 $\mathrm{mg} / \mathrm{kg}$ ) subcutaneously and blood was collected from the abdominal aorta to obtain serum.

\section{Cell viability assay}

Cell viability of RAW 264.7 cells was evaluated using a Cell Counting Kit-8 (CCK-8). Cells $(1 \times$ $10^{4}$ cells/well) were transplanted into a 96-well microplate and incubated for $24 \mathrm{~h}$ at $37^{\circ} \mathrm{C}$. PLV was added to each well to make the final concentrations of 25, 50,100,200, 400 and 800 $\mu \mathrm{g} / \mathrm{mL}$, and incubated for another $24 \mathrm{~h}$. CCK-8 reagent was added to each well and incubated for $4 \mathrm{~h}$. Absorbance was read at $450 \mathrm{~nm}$ using a microplate reader. Cell viability was calculated using Eq 1.

Cell viability $(\%)=\left(A_{1} / A_{0}\right) 100$

where $A_{1}$ is the absorbance of PLV treated cells, and $A_{0}$ the absorbance of PLV untreated cells.

\section{Determination of inflammatory cytokines by ELISA}

Cells were treated with PLV $(50,100$ and $200 \mu \mathrm{g} / \mathrm{mL})$ for $4 \mathrm{~h}$, and then LPS $(1 \mu \mathrm{g} / \mathrm{mL})$ was added and incubated for another $24 \mathrm{~h}$. Levels of IL-6, IL-1 $\beta$, IL-10 and TNF- $\alpha$ in the supernatants of cell culture were measured using commercial ELISA kits following the manufacturer's instructions.

\section{Real-time reverse transcription polymerase chain reaction (real-time $\mathrm{PCR}$ )}

A fluorescence quantitative Light Cycler 480 Real Time PCR system (Roche, Sweden) was used to determine the mRNA expressions of TNF- $\alpha$, IL-6, $\mathrm{IL}-1 \beta$, and IL-10. Total RNA was extracted from the cells by Trizol reagent and equal amounts of RNA was reverse transcribed to cDNA using SYBR Green qPCR SuperMix (Invitrogen) following the manufacturer's protocol. The PCR oligonucleotide primers are shown in Table 2. The $\Delta \Delta \mathrm{Ct}$ method was used to calculate the relative gene expression.

\section{Statistical analysis}

Statistical analysis was carried out using SPSS software 18.0 for Windows (SPSS Inc., Chicago, IL, USA). All data are presented as mean \pm standard deviation (SD) and comparison between two groups was performed by Student's $t$ test. $P<0.05$ was considered statistically significant.

\section{RESULTS}

\section{Optimized extraction conditions}

The experimental results from orthogonal test were shown in Table 3. The factors were quantitatively analyzed using evaluation indices $\mathrm{K}$ and $\mathrm{R}$. It is known that the factor with the larger $R$ value have the greater effect on the extraction yield. Thus, the influential order of the three factors was $A>B>C$. Furthermore, variance analyses (ANOVA) in Table 4 shows that the effects of three tested factors $(p<0.01, p<0.05$ and $p<0.05$ for $A, B$ and $C$, respectively) on extraction yield were significant. Based on the $R$ values and ANOVA, the optimum extraction conditions for PLV were: extraction time (120 $\mathrm{min})$, ratio of liquid to raw material $(20 \mathrm{~mL} / \mathrm{g})$ and ethanol concentration (50 \%). A validation experiment were carried out using the optimum extraction conditions, and resulted in a total yield of $43.34 \pm 1.23 \mathrm{mg} / \mathrm{g}$.

\section{Effect of PLV on inflammatory cytokines in rat serum}

The results are shown in Figure 1. After model construction, the serum levels of IL- $6, \mathrm{IL}-1 \beta$ and TNF- $\alpha$ significantly increased $(p<0.01$, compared with the control group).

Table 2: Oligonucleotide primers for real-time RT-PCR analysis

\begin{tabular}{|c|c|}
\hline Target gene & Primer sequence \\
\hline TNF- $\alpha$ & $\begin{array}{l}\text { F: 5'-TTCTGTCTACTGAACTTCGGGGTGATCGGTCC-3' } \\
\text { R: 5'-GTATGAGATAGCAAATCGGCTGACGGTGTGGG-3' }\end{array}$ \\
\hline IL-6 & $\begin{array}{l}\text { F: 5'-TCCAGTTGCCTTCTTGGGAC-3' } \\
\text { R: 5'-GTGTAATTAAGCCTCCGACTTG-3' }\end{array}$ \\
\hline 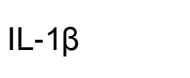 & $\begin{array}{l}\text { F: 5'-ATGGCAACTGTTCCTGAACTCAACT-3' } \\
\text { R: 5'-CAGGACAGGTATAGATTCTTTCCTTT-3' }\end{array}$ \\
\hline IL-10 & $\begin{array}{l}\text { F: 5'-TCT ACA AGGCCA TGA ATG AG-3' } \\
\text { R: 5'-GAG AGA GGTACA AAC GAG G-3' }\end{array}$ \\
\hline
\end{tabular}


Table 3: Orthogonal design and experimental results

\begin{tabular}{|c|c|c|c|c|c|}
\hline No. & $\mathbf{A}$ & B & C & D & Yield $(\mathrm{mg} / \mathrm{g})$ \\
\hline 1 & 1 & 1 & 1 & 1 & 25.1 \\
\hline 2 & 1 & 2 & 2 & 2 & 37.2 \\
\hline 3 & 1 & 3 & 3 & 3 & 35.3 \\
\hline 4 & 2 & 1 & 2 & 3 & 38.5 \\
\hline 5 & 2 & 2 & 3 & 1 & 42.5 \\
\hline 6 & 2 & 3 & 1 & 2 & 37.5 \\
\hline 7 & 3 & 1 & 3 & 2 & 26.6 \\
\hline 8 & 3 & 2 & 1 & 3 & 28.8 \\
\hline 9 & 3 & 3 & 2 & 1 & 32.7 \\
\hline K1 & 32.533 & 30.067 & 30.467 & 33.433 & \\
\hline K2 & 39.500 & 36.167 & 36.133 & 33.767 & \\
\hline K3 & 29.367 & 35.167 & 34.800 & 34.200 & \\
\hline $\mathrm{R}$ & 10.133 & 6.100 & 5.666 & 0.767 & \\
\hline
\end{tabular}

Table 4: Analysis of variance of the studied factors

\begin{tabular}{lccccc}
\hline Source & $\begin{array}{c}\text { Sum of } \\
\text { squares }\end{array}$ & $\begin{array}{c}\text { Degree of } \\
\text { freedom }\end{array}$ & F-ratio & $\mathbf{F}_{\mathbf{0 . 0 5}} / \mathbf{F}_{\mathbf{0 . 0 1}}$ & Significant \\
\hline A & 161.247 & 2 & 181.789 & 99.00 & $*$ \\
B & 64.220 & 2 & 72.401 & 19.00 & $*$ \\
C & 52.667 & 2 & 59.377 & 19.00 & $*$ \\
D & 0.887 & 2 & 1.000 & 19.00 & \\
Error & 0.89 & 2 & & & \\
\hline
\end{tabular}

Compared with the rats in the model group, serum levels of the three inflammatory factors significantly decreased $(p<0.05, p<0.01$ and $p$ $<0.01$, respectively) by treating with PLV at the concentrations of 25, 50 and $100 \mathrm{mg} / \mathrm{kg}$. However, the serum level of IL-10 in PLV treated rats significantly increased when compared with model rats at the concentrations of 50 and 100 $\mathrm{mg} / \mathrm{kg}(p<0.01)$.
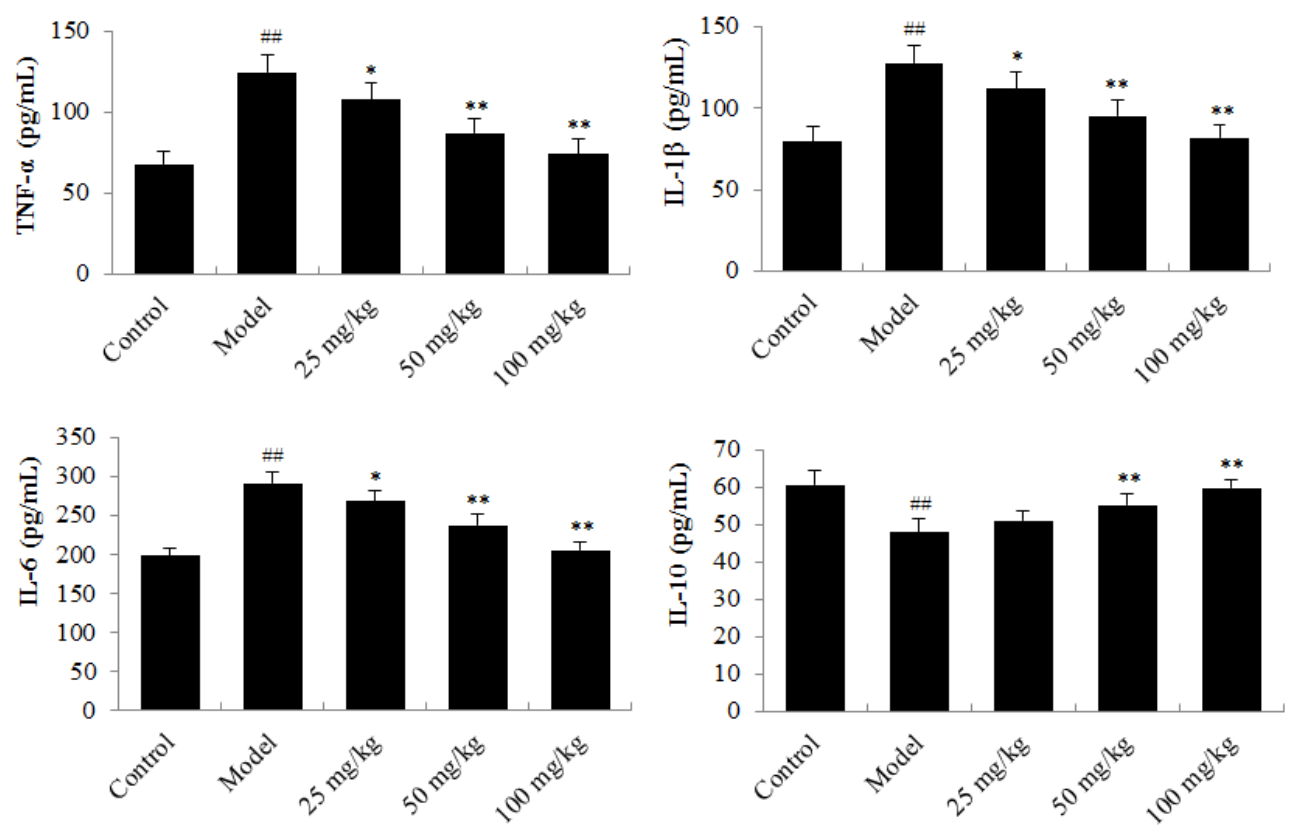

Figure 1: Effects of PLV on levels of TNF- $\alpha$, IL-6, IL-1 $\beta$ and IL-10 in the serum of rats 


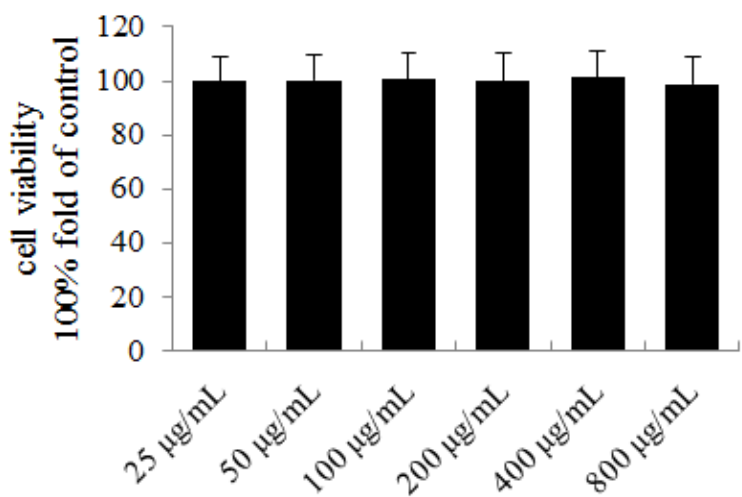

Figure 2: Effect of PLV on cell viability of RAW264.7 cells

\section{Effects of PLV on inflammatory cytokines in vitro}

Effects of PLV on the levels of cytokines (TNF- $\alpha$, IL-1 $\beta$, IL-6 and IL-10) in RAW264.7 cells were determined by ELISA. As shown in Figure 3, LPS stimulation significantly increased the levels of the cytokines $(p<0.01)$. Compared with LPSstimulated model cells, the levels of TNF- $\alpha$, IL-6, IL-1 $\beta$ significantly decreased, whereas the level of IL-10 significantly increased in PLV-treated (50, $\quad 100$ and $200 \mu \mathrm{g} / \mathrm{mL}$ ) cells with a concentration-dependent manner.
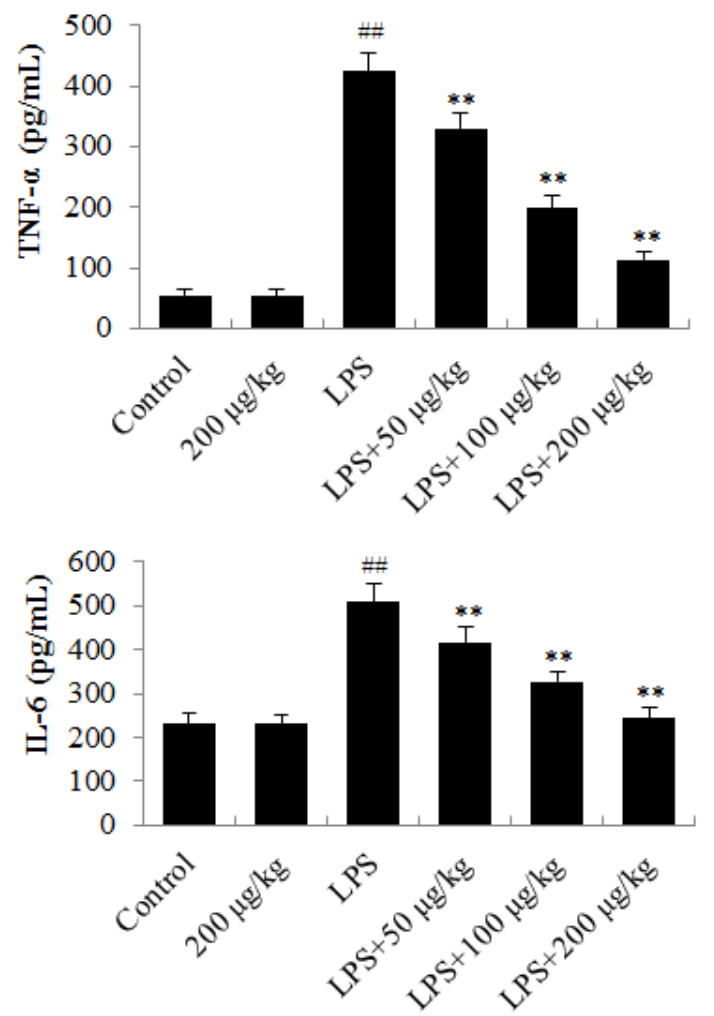

Effect of PLA on expression of mRNA of cytokines

To further investigate the anti-inflammatory mechanism of PLV, real-time RT-PCR was employed to investigate the mRNA levels of inflammatory cytokines. As shown in Figure 4, LPS treatment significantly increased the mRNA expression of the cytokines $(p<0.01)$. The mRNA expression of cytokines (TNF- $\alpha$, IL- 6 and IL-1 $\beta$ ) were significantly down-regulated by treatment of PLA (50, 100 and $200 \mu \mathrm{g} / \mathrm{mL})$. The mRNA expression of IL-10 was significantly upregulated by treating PLV (100 and $200 \mu \mathrm{g} / \mathrm{mL})$.

\section{DISCUSSION}

It is reported that traditional Chinese medicines (TCM) may provide a promising strategy to prevent chronic inflammatory diseases $[11,12]$. Flavonoids have been isolated and characterized from a variety of plants $[13,14]$, and they are also dominant bioactive constituents in PTJ [6,7]. In the present study, flavonoids were extracted from PTJ and the extraction conditions were optimized by employing an orthogonal design. A total PLV yield of $43.34 \pm 1.23 \mathrm{mg} / \mathrm{g}$ was obtained by validation experiments and PLV was proved to have obvious anti-inflammatory effects on chronic pelvic inflammatory disease by in vivo and in vitro experiments.
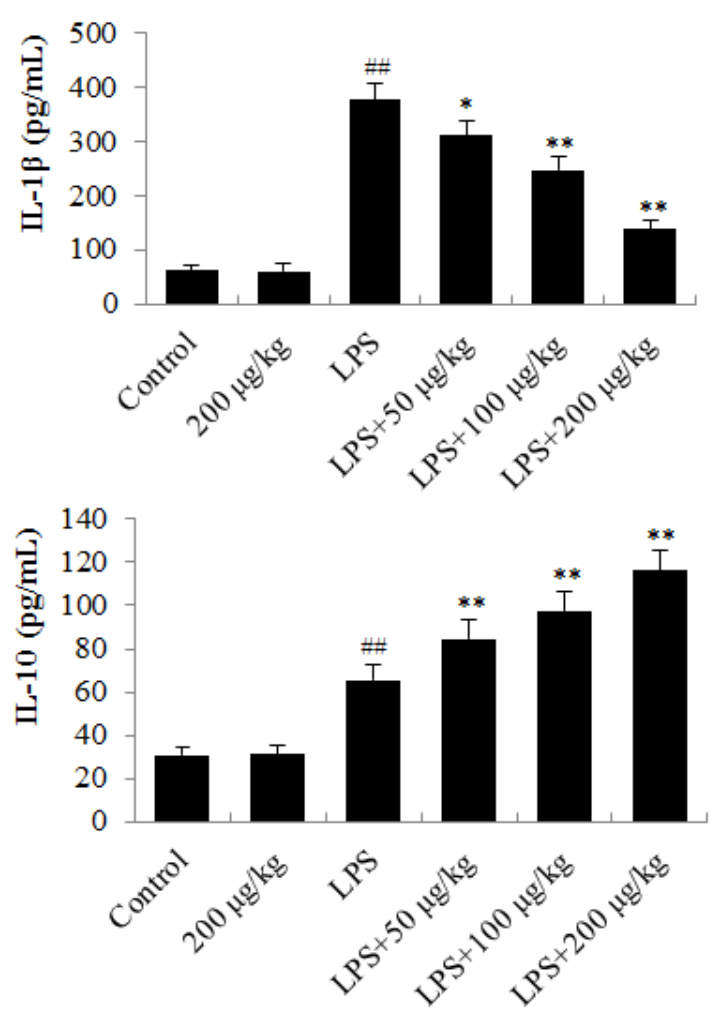

Figure 3: Effects of PLV on the levels of cytokines in RAW264.7 cells 

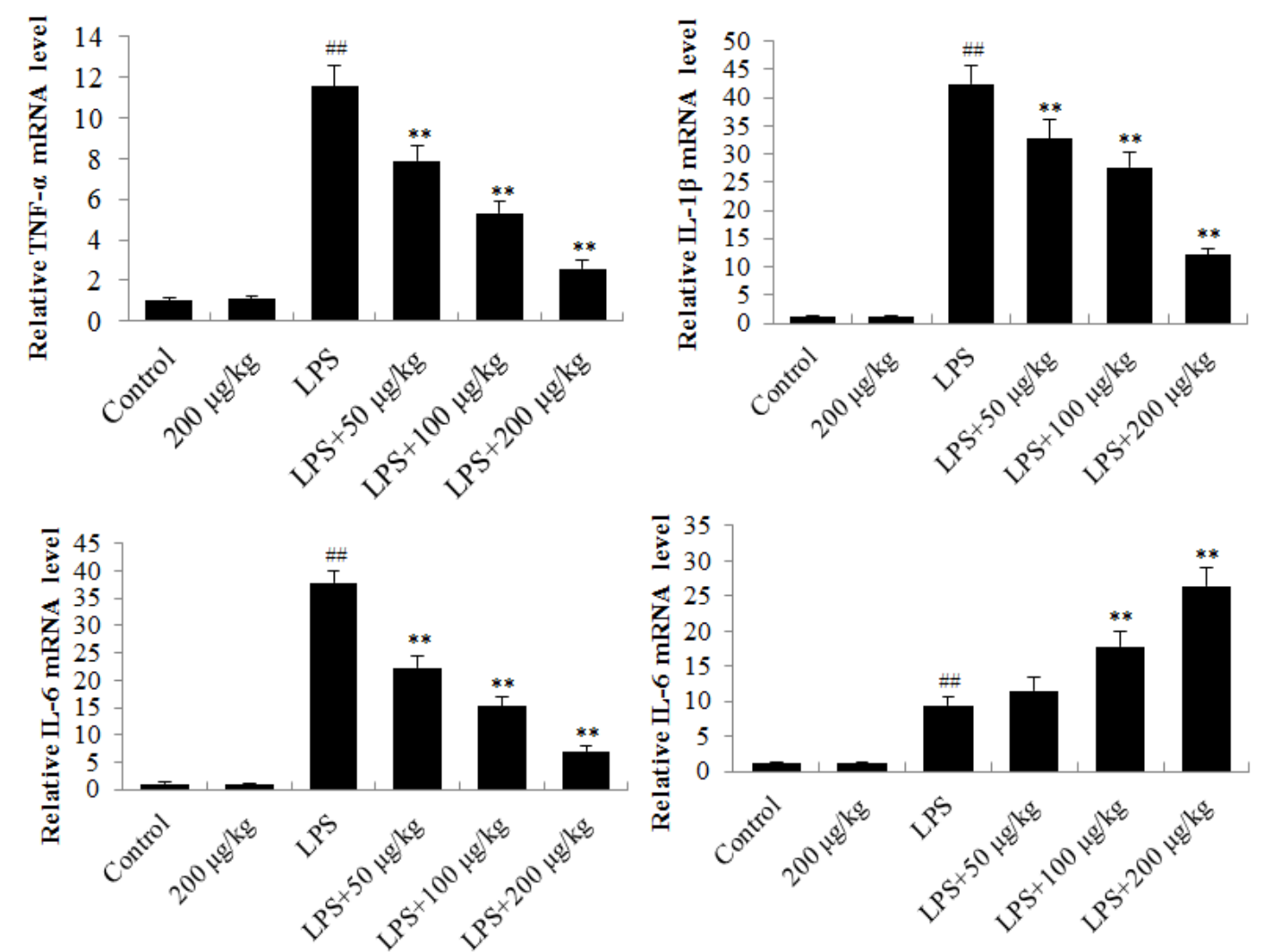

Figure 4: Effect of PLA on mRNA expression TNF- $\alpha$, IL-6, IL-1 $\beta$, and IL-10 in RAW264.7 cells

Inflammatory response in upper genital tract can be initiated and propagated by the overproduction of pro-inflammatory cytokines, which can also activate local immune cells and increase chemokines productions. Chemokines promote the infiltrations of hematopoietic immune cells, and then the productions of proinflammatory cytokines are further increased and the inflammatory response intensified $[15,16]$. Hence, inflammatory cytokines play a central role in inflammatory response. In the present study, the effects of PLV on serum levels of inflammatory cytokines were evaluated in the PID rats. The results indicated that PLV decreased the serum levels of TNF- $\alpha$, IL- 6 and $\mathrm{IL}-1 \beta$, while increased the IL-10 level in the rats.

A large number of studies have demonstrated that overproduction of different pro-inflammatory mediators and cytokines by macrophages may be the major factor in the process of inflammatory responses $[17,18]$. In the present study, the RAW264.7 cells were used to evaluate the effects of PLV on inflammatory cytokines. The results showed that treatment of PLV significantly suppressed the levels of TNF-a, IL$1 \beta$, IL-6, whereas increased the IL-10 level in LPS-stimulated RAW264.7 cells. In addition, the results of mRNA expression were consistent with the results of inflammatory cytokines production.

\section{CONCLUSION}

The findings of the present study indicate that PLV possesses significant anti- inflammatory effects on chronic pelvic inflammation, and that the mechanism is closely related to a decrease in the levels of TNF- $\alpha$, IL- $1 \beta$ and IL- 6 , as well as an increase in IL-10 level. Thus, PLV has potentials to be developed into anti-inflammatory drugs for chronic pelvic inflammation in the future.

\section{DECLARATIONS}

\section{Acknowledgement}

None.

\section{Conflict of Interest}

No conflict of interest associated with this work.

\section{Contribution of Authors}

The authors declare that this work was done by the authors named in this article and all liabilities pertaining to claims relating to the content of this article will be borne by them.

\section{Open Access}

This is an Open Access article that uses a fund- 
ing model which does not charge readers or their institutions for access and distributed under the terms of the Creative Commons Attribution License (http://creativecommons.org/licenses/by/ 4.0) and the Budapest Open Access Initiative (http://www.budapestopenaccessinitiative.org/rea d), which permit unrestricted use, distribution, and reproduction in any medium, provided the original work is properly credited.

\section{REFERENCES}

1. Zou W, Xiao Z, Wen X, Luo J, Chen S, Cheng Z, Xiang $D$, Hu J, He J. The anti-inflammatory effect of Andrographis paniculata (Burm. f.) Nees on pelvic inflammatory disease in rats through down-regulation of the NF-KB pathway. BMC Complem Altern Med 2016; 16(1): 483-483.

2. Liu $B Q$, Gong $X$, Jin Z. Effect of Danzhi decoction on expression of angiogenesis factors in patients with sequelae of pelvic inflammatory disease. Asian Pac $J$ Trop Med 2014; 7(12): 985-990.

3. Mitchell C, Prabhu M. Pelvic inflammatory disease: current concepts in pathogenesis, diagnosis and treatment. Infect Dis Clin North Am 2013; 27(4): 793809.

4. Dhasmana D, Hathorn E, McGrath R, Tariq A, Ross JD. The effectiveness of nonsteroidal anti-inflammatory agents in the treatment of pelvic inflammatory disease: a systematic review. Syst Rev 2014; 3: 79-79.

5. Park ST, Lee SW, Kim MJ, Kang YM, Moon HM, Rhim CC. Clinical characteristics of genital chlamydia infection in pelvic inflammatory disease. BMC Women's Health 2017; 17(1):5-5.

6. Xin-Jia $Y$, Wei L, Ying Z, Ning C, Ying $X$, Jian W, Tan W, Yue L, Zheng $X$. A New Biphenyl Neolignan from Leaves of Patrinia villosa (Thunb.) Juss. Pharmacogn Mag 2016; 12(45): 1-3.

7. Wen-Lan L, Xue Z, Xin-Xin Y, Shuai W, Lin Z, Huan-Jun $Z$, Yong-Rui B, Chen-Feng J, Ning C, Zheng X. Species classification and bioactive ingredients accumulation of BaiJiangCao based on characteristic inorganic elements analysis by inductively coupled plasma-mass spectrometry and multivariate analysis. Pharmacogn Mag 2015; 11(44): 756-763.

8. Guo CY, Wang J, Hou Y, Zhao YM, Shen LX, Zhang DS. Orthogonal test design for optimizing the extraction of total flavonoids from Inula helenium. Pharmacogn Mag 2013; 9(35): 192-195.
9. "Principles of Laboratory Animal Care" (NIH publication no. 85-23, revised 1985). Available from: http://grants 1.nih.gov/grants/olaw/references/phspol.htm

10. Zou W, Zhou H, Hu J, Zhang L, Tang Q, Wen X, Xiao Z, Wang W. Rhizoma Smilacis Glabrae inhibits pathogeninduced upper genital tract inflammation in rats through suppression of NF-KB pathway. J Ethnopharmacol 2017; 202: 103-113.

11. Sun H, Cai W, Wang X, Liu Y, Hou B, Zhu X, Qiu L. Vaccaria hypaphorine alleviates lipopolysaccharideinduced inflammation via inactivation of NFKB and ERK pathways in Raw 264.7 cells. BMC Complement Altern Med 2017, 17(1):120.

12. Sun $D$, Yan $Q, X u X$, Shen $W, X u C$, Tan J, Zhang $H, L i$ $L$, Cheng H. LC-MS/MS analysis and evaluation of the anti-inflammatory activity of components from BushenHuoxue decoction. Pharm Biol 2017; 55(1): 937945.

13. Chen $S$, Wu BH, Fang JB, Liu YL, Zhang HH, Fang $L C$, Guan L, Li SH. Analysis of flavonoids from lotus (Nelumbo nucifera) leaves using high performance liquid chromatography/photodiode array detector tandem electrospray ionization mass spectrometry and an extraction method optimized by orthogonal design. J Chromatogr A 2012; 1227: 145-153.

14. Shen $A Z, \mathrm{Li} X, \mathrm{Hu} W$, Chen FH. Total flavonoids of Bidens bipinnata $L$. ameliorate experimental adjuvantinduced arthritis through induction of synovial apoptosis. BMC Complement Altern Med 2015; 15(1): 437-437.

15. Rong J, Zheng $H$, Liu M, Hu X, Wang $T$, Zhang $X$, Jin $F$, Wang $L$. Probiotic and anti-inflammatory attributes of an isolate Lactobacillus helveticus NS8 from Mongolian fermented koumiss. BMC Microbiol 2015; 15: 196-196.

16. Adewoyin M, Mohsin SM, Arulselvan P, Hussein MZ, Fakurazi S. Enhanced anti-inflammatory potential of cinnamate-zinc layered hydroxide in lipopolysaccharidestimulated RAW 264.7 macrophages. Drug Des Devel Ther 2015; 9: 2475-2484.

17. Sun H, Cai W, Wang X, Liu Y, Hou B, Zhu X, Qiu L. Vaccaria hypaphorine alleviates lipopolysaccharideinduced inflammation via inactivation of NFKB and ERK pathways in Raw 264.7 cells. BMC Complement Altern Med 2017; 17(1): 120-120.

18. Wang G, Hu Z, Fu Q, Song X, Cui Q, Jia R, Zou Y, He C, $L i L$, Yin $Z$. Resveratrol mitigates lipopolysaccharidemediated acute inflammation in rats by inhibiting the TLR4/NF-KBp65/MAPKs signaling cascade. Sci Rep 2017; 7: 45006. 